\title{
Ody do wspólnoty - interpretacja porównawcza
}

\author{
Odes to the Community - comparative interpretation
}

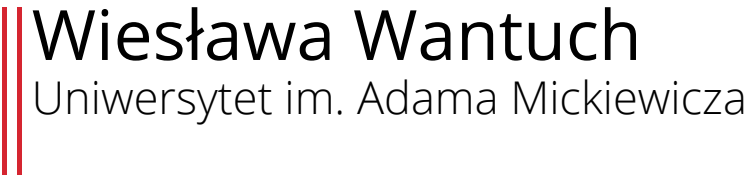

\begin{abstract}
This article proposes a comparative interpretation of two types of texts: typographic and literary, i.e. different versions of writing solidarność, which are written in three different fonts, so called Solidaryca and Ode to Youth by Adam Mickiewicz. Common categories of graphic analysis (background, form of the font, its colour etc) allow for a new perspective to look at the poem. Both types of text are compared as persuasive expressions of meaning, characteristics and mutual dependencies between the community and the individual in certain socio-historical contexts.
\end{abstract}

Key words: school methodology, comparative interpretation, categories of typographic analysis, community.

Streszczenie: $W$ artykule zaproponowano interpretację porównawczą dwóch typów tekstów: typograficznych w zestawieniu z literackim. Są to różne wersje napisu solidarność, w których wykorzystuje się fonty tzw. solidarycy oraz Oda do młodości Mickiewicza. Kategorie opisu oczywiste przy analizie graficznej (tło, kształt czcionki, kolor itp.) pozwalają z nowej perspektywy spojrzeć także na znany wiersz. Oba typy tekstów są zestawiane jako perswazyjne wypowiedzi o sensie, cechach i zależnościach wspólnoty oraz jednostki poszukującej w niej swego miejsca, w określonych kontekstach historyczno-społecznych.

Słowa kluczowe: interpretacja porównawcza, kategorie analizy typograficznej, wspólnota.

Przynależność do wspólnot jest dla człowieka nie tylko koniecznością, ale i wartością. Co więcej - antropolodzy uzasadniają m.in. hipersocjalnością niepowstrzymaną ekspansję homo sapiens i zwycięstwo tego gatunku nad innymi człekokształtnymi kuzynami:

Z jednej strony potrafimy się rzucić na pomoc nieznajomemu, ale z drugiej z łatwością sprzymierzamy się z innymi obcymi, by ruszyć na bezlitosną wojnę z sąsiednią grupą. (...) ta skłonność do kooperacji (...) nie jest czymś wyuczonym, ale jest cechą uwarunkowaną genetycznie i obecną tylko w naszym gatunku

- twierdzi Curtis W. Marean (Marean 2015). 
Współczesny Europejczyk tęskni do wspólnot, a zarazem zazdrośnie strzeże swej indywidualności przed wspólnotowym zawłaszczeniem. Młodzi ludzie są szczególnie podatni na wahania między pragnieniem przynależności a niezależności, dlatego refleksja nad mechanizmami tworzenia się i trwania wspólnot wydaje się potrzebą momentu rozwojowego, w którym znajdują się i jako jednostki, i jako uczestnicy cywilizacji zachodnioeuropejskiej i wirtualnej. Ta ostatnia staje się ich naturalnym środowiskiem, a im młodsi, tym bardziej nieświadomie i/lub bezrefleksyjnie ulegają cudom techniki aż po uzależnienia od tego, co miało być narzędziem.

Poniższa propozycja może skłonić młodych ludzi do przyjrzenia się swoim reakcjom i emocjom z dystansu, który niekoniecznie je schłodzi, ale być może pozwoli nieco zracjonalizować poszukiwania tego, co wspólne.

\section{Dlaczego interpretacja porównawcza}

Pionierka interpretacji porównawczej na gruncie polskiej dydaktyki Bożena Chrząstowska (Chrząstowska 2009, 89-121) - jako warunek doboru tekstów do porównania wskazuje ich samozwrotność interpretacyjną. Spotkanie, a czasem zderzenie dwu i więcej tekstów, powoduje, że oświetlają się nawzajem z nie zawsze oczywistej perspektywy. Chrząstowska zalecała zestawianie takich tekstów, które katalizując osobistą i kreatywną lekturę, zarazem mobilizują czytelnika do dyscypliny argumentacyjnej. Dodatkowym walorem takiego porównania (istotnym z dydaktycznego punktu widzenia) może stać się funkcjonalne użycie terminologii (np. z zakresu poetyki) zamiast tworzenia ad hoc parafraz nie zawsze precyzyjnie ujmujących właściwości tekstów. W użyciu terminów, dopiero gdy finalizują one kształtowanie pojęcia, przejawia się ekonomia językowa. Z kolei na trwałość zapamiętania i kompetentne posługiwanie się nimi ma wpływ również kontekst, w jakim zostały wprowadzone i/lub ugruntowane. Przy czym przywoływane, zwłaszcza samodzielnie przez uczniów, konteksty mogą odsłaniać nie tylko szkolną wiedzę, ale i indywidualne pasje młodych ludzi z pozoru mało związane ze spisem lektur. Interpretacja porównawcza funkcjonalizuje więc posiadaną wiedzę, ale i umożliwia samodzielne uczniowskie odkrycia, co - jak wiadomo - jest czynnikiem motywującym do dalszych postępów, w tym przypadku interpretacyjnych.

Jako etapy postępowania interpretacyjnego, a potem kryteria oceny interpretacji porównawczej Chrząstowska proponuje:

- odkrycie zasady porównania: podobieństwa, różnice pozwalające sproblematyzować zestawienie i/lub określić jego temat,

- pociąga to za sobą wybór elementów poddanych analizie, a tym samym sprzyja porządkowi interpretacji,

- to z kolei rzutuje na jakość opisu analitycznego odsłaniającego relacje między elementami i ich funkcje ze względu na spójność interpretacji, 
- która finalnie ma gwarantować pełne odczytanie sensu porównywanych utworów z wykorzystaniem wcześniejszej analizy, zaś dobór kontekstu - wydobycie sensu porównywanych tekstów oraz uprawomocnienie wartościowania.

Założony porządek interpretacji i kompletność, do których zmierza się przez opis i analizę, wyraźnie wskazują na strukturalistyczne pochodzenie wzorca. Nie warto go jednak pochopnie odrzucać - dydaktyka wymaga przecież kategoryzowania, przeciwstawiania, porównywania, a temu służą wszelkie, nawet z założenia tymczasowe „hipotezy ładu”.

Korzystając z tych wskaźników interpretacji porównawczej, spróbujmy rozważyć sens i cechy wspólnoty jako naturalnej formy samoorganizacji ludzi, którzy - aby budować własną tożsamość - potrzebują wsparcia podobnie myślących, czujących i działających. Materiałem służącym refleksji nad wspólnotą jako potrzebą antropologiczną będą napisy solidaryca oraz Oda do młodości Adama Mickiewicza. Oczywiście nic nie stoi na przeszkodzie, aby kolejność: punkt wyjścia - punkt dojścia zmienić, tu zaproponowanemu przyświecała zasada dydaktyczna od łatwiejszego do trudniejszego.

\section{Od napisu do napisu, czyli wybór porównywanych elementów}

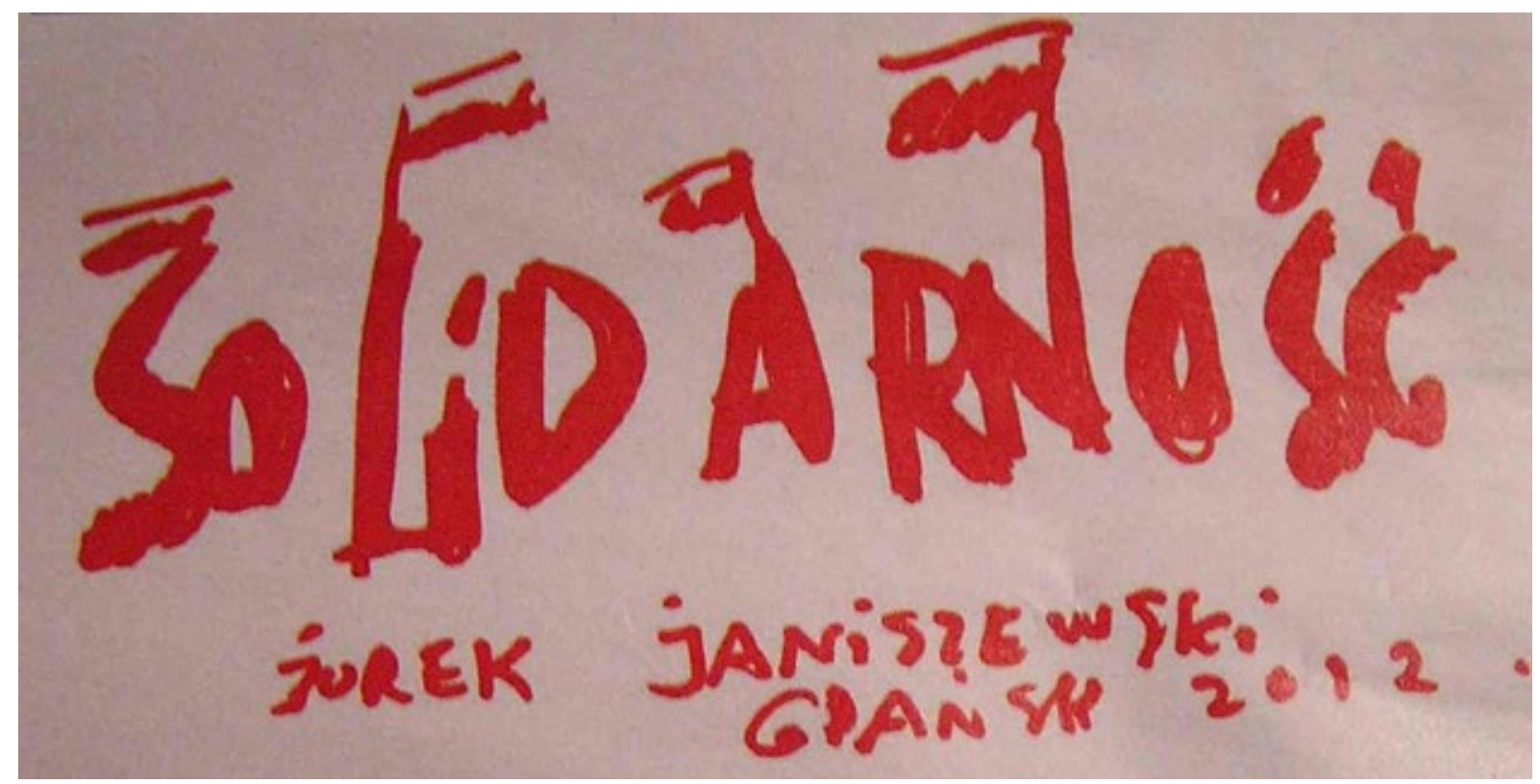

Załącznik nr 1

Na początek eksponujemy tylko napis Solidarność w kształcie znanym ze strajków 1980 r. (zob. zał. nr 1). Opis czcionki uczniowie mogą sporządzić, korzystając z tabelki na wzór poniższej lub sami proponując kategorie, które przyłożą ponownie do drugiego napisu z roku 2012 (zob. zał. nr 2), a potem ewentualnie i do trzeciego (zob. zał. nr 3). 


\begin{tabular}{|l|l|l|}
\hline & NAPIS 1 & NAPIS 2 \\
\hline Kolor liter i tła & & \\
\hline Kształt i układ liter & & \\
\hline $\begin{array}{l}\text { Inne elementy graficzne } \\
\text { (oprócz liter) }\end{array}$ & & \\
\hline $\begin{array}{l}\text { Znaczenie słowa } \\
\text { jak w słowniku) }\end{array}$ & & \\
\hline $\begin{array}{l}\text { Wpływ grafiki napisu } \\
\text { na Twój odbiór znaczenia } \\
\text { słowa }\end{array}$ & & \\
\hline
\end{tabular}

Późniejsze napisy wyraźnie nawiązują do historycznie pierwszego i dopiero w porównaniu z nim stanowią komentarz do czasu, jaki je dzieli, choć możliwa zdaje się także ich interpretacja w izolacji. Wówczas część uczniów otrzymuje jeden, część drugi napis - zderzenie zaś obu opisów może przydać rozmowie dramatyzmu.

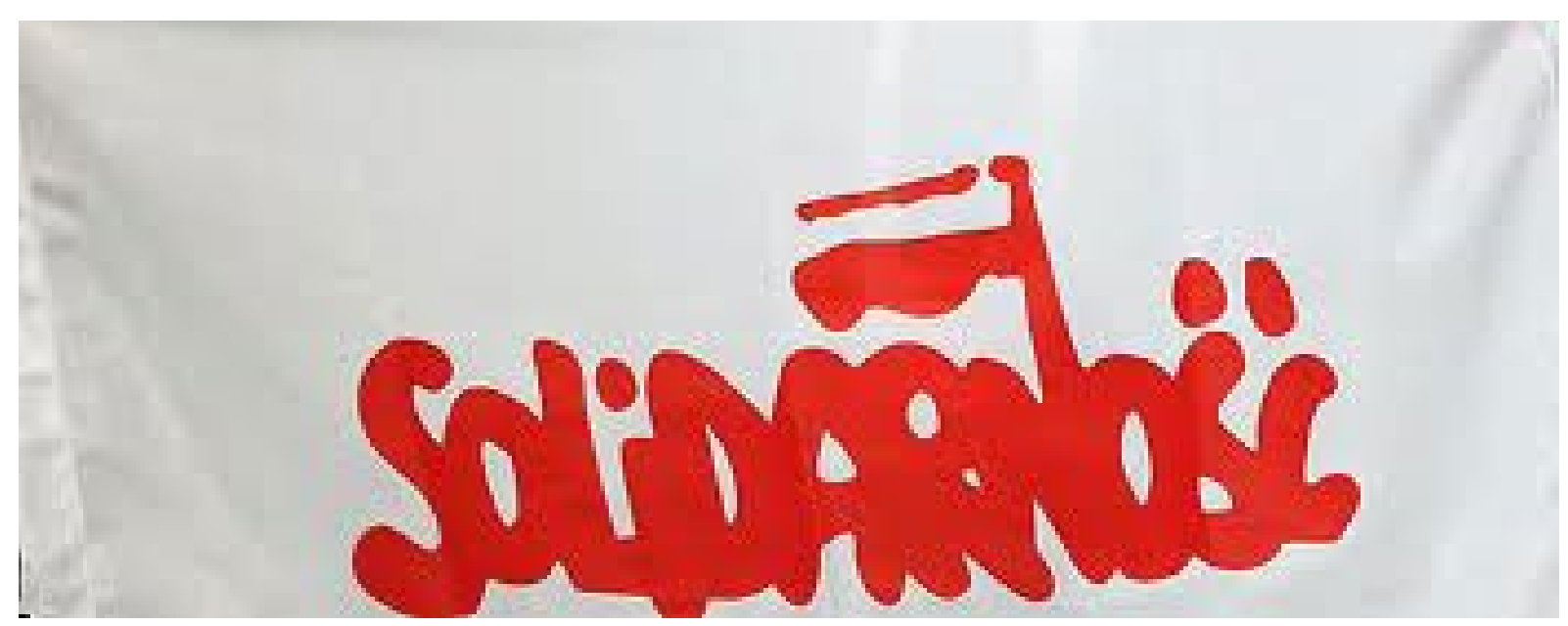

Załącznik nr 2

Wszystkie „logo" ${ }^{1}$ operują czerwonym kolorem. Spośród wielu znaczeń powiązanie tej barwy ze znaczeniem czerwonego sztandaru - międzynarodowego godła proletariatu - dla uczniów nie musi być oczywiste. Trzeba to ustalić, bo dopiero symbolika koloru uświadamia jaskrawą ironię zastosowania go w 1980 r., kiedy robotnicy strajkowali przeciwko robotniczo-chłopskiemu rządowi.

O historii powstania dwóch pierwszych napisów opowiada artykuł Pawła Zbierskiego Nowe logo na https://www.tygodnikpowszechny.pl/nowe-logo-17050 (dostęp: 01.09.2015) lub w dodatku specjalnym Solidarność dzisiaj do: „Tygodnik Powszechny” 09.09.2012 (nr 37). W wersji internetowej artykułu napis jest bardziej okaleczony przez przycięcie początkowej i końcowej litery, ale tym samym wydaje się fragmentem większej całości, wykraczającej poza słowo solidarność. Zmiana tła tak jak na zał. 2.- to nie jedyna zmiana, jakiej poddano logo „Solidarności” zob. http://natemat.pl/7585,slynny-plakat-wyborczy-solidarnosci-zobacz-jak-wykorzystywany-jest-w-polityce-i-kulturze-i-kto-dostal-go-w-prezencie (dostęp: 27.09.2015) lub hasło: obrazy dla grafika napisu solidarność w dowolnej wyszukiwarce internetowej. Trzeci (zał. 3) napis pojawił się na okładce „Polityki”23.09-29.09.2015 (nr 39). 


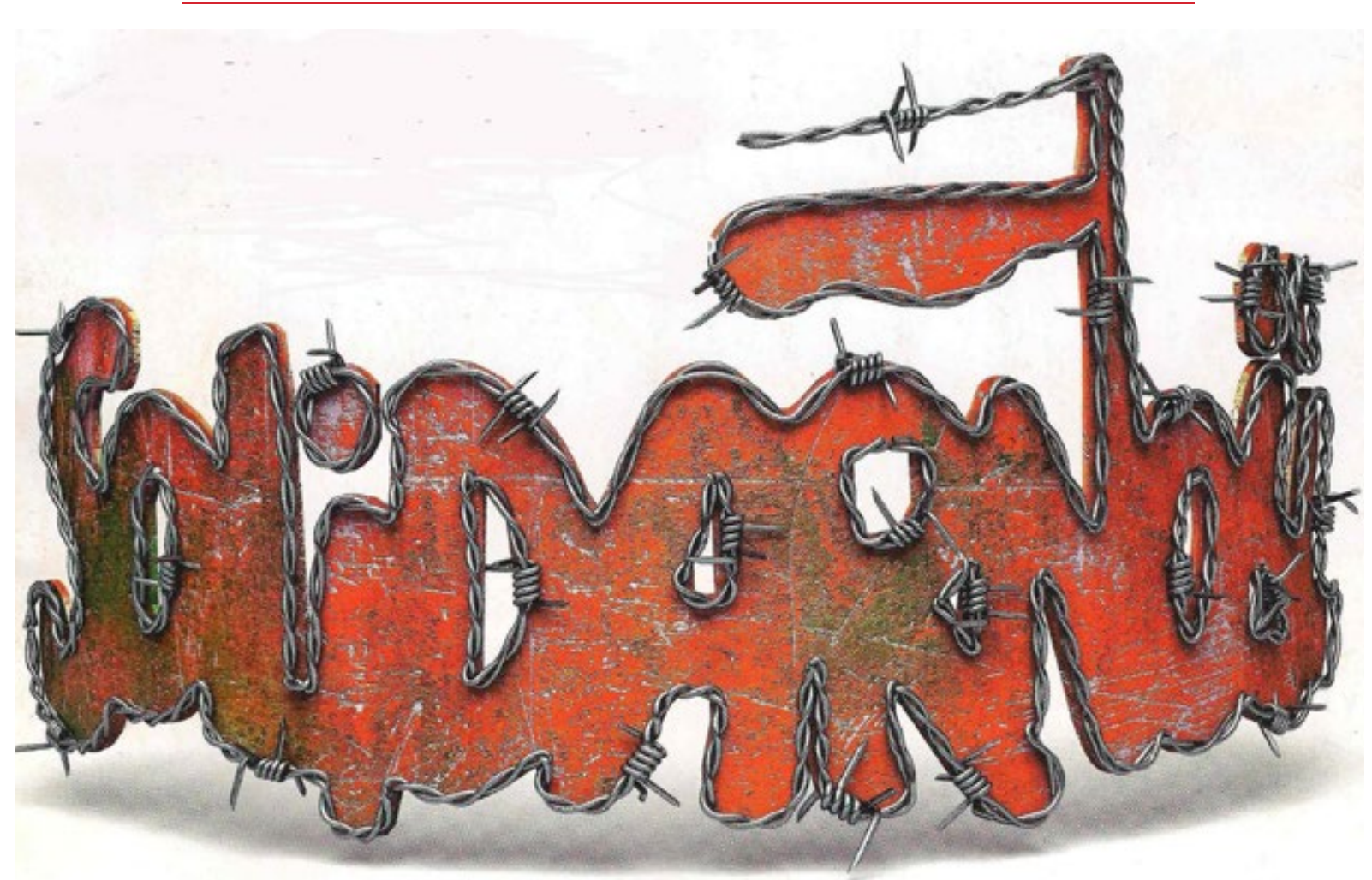

Załącznik nr 3

W hasłach rozwieszanych wtedy w przestrzeni publicznej krajów należących do obozu socjalistycznego białe lub czarne liternictwo zazwyczaj eksponowano na czerwonym tle. Robotnicy z lat 80. odzyskiwali więc symbolikę zawłaszczoną przez rządy komunistyczne po 1945 r., a zarazem, układając kolory $\mathrm{w}$ odwrotnej konfiguracji, odcinali się od rządzących, przeciwko którym właśnie wystąpili. Tym samym wskazywano nie tyle na internacjonalistyczny, ile na narodowy charakter protestu i wyboru wartości. Biało-czerwony sztandar wyprowadzony z litery „n” tę polskość buntu jeszcze podkreślał ${ }^{2}$. W sierpniu 1980 r. nikt przecież nie zdawał sobie sprawy, jak rozległy proces historycznych przemian został zapoczątkowany na Wybrzeżu. Masywne liternictwo, dodatkowo dyscyplinowane konturem obrysowującym całe słowo, nadaje słowu zwartość i moc. Litery czasami wręcz zlewają się i tym samym wspierają nawzajem w „marszu” w jednym kierunku i pod jednym sztandarem. Pochylenie liter w lewo lub (w prawo) zwiększa dynamikę całego napisu, sugerując zmaganie się z jakimś oporem, co jest już nieco późniejszą modyfikacją. Pierwotnie napis był dumnie wyprostowany.

W prezentowanej tu wersji napisu z roku 2012 tło ma odcień różowawy (tzw. brudny róż lub róż indyjski) i podobnie przybrudzona jest biel na flagach, z których dwie powiewają w przeciwnym kierunku niż dwie pozostałe. Czcionki grupują się pod nimi po dwie, trzy, dzieląc napis nawet nie

2 „Solidarność” bardzo szybko zyskała świadomość uniwersalności własnych postulatów, a zwłaszcza tego dotyczącego tworzenia wolnych związków zawodowych, o czym świadczy Posłanie do ludzi pracy Europy Wschodniej przyjęte na I Krajowym Zjeździe Delegatów NSZZ „Solidarność” we wrześniu 1981 r. 
na sylaby, ale przypadkowe cząstki. Ostatnie trzy litery nie mają żadnego sztandaru, a znaki diakrytyczne nad „i "ś " $\mathrm{i}$ „ć” są mniej regularne niż niegdyś. Słowo, nie dość, że kilkuczęściowe, zostało namalowane niestarannie, jakby pospiesznymi pociągnięciami pędzla, dlatego litery różnią się wysokością bardziej niż w napisie z roku 1980.

Przedostatnia rubryka tabelki wymaga sięgnięcia do słownika po to, aby oba napisy odczytać jako historyczne komentarze/wizje wspólnoty, którą przenika (ponoć) duch współodpowiedzialności, współdziałania, zgodności w jakiejś sprawie, co do jakiegoś celu. Choć solidarność bezpośrednio pochodzi z języka francuskiego (fr. solidaire), wcześniejsze źródła tego słowa biją w łacinie (in solidum - za całość, obejmując wszystko). Władysław Kopaliński dodaje w haśle słownikowym, że „solidaryzm wymierzony głównie przeciw marksistowskiej teorii walki klasowej” jako ruch społeczno-polityczny głosi jedność interesów wszystkich klas (Kopaliński 1971,701), czyli ludzi w ogóle. Radosław Markowski precyzuje to dobitnie:

Z wielkiej trójcy rewolucji francuskiej: wolność, równość, braterstwo, to ostatnie trzeba zastąpić właśnie solidarnością. (...) Solidarność - a właściwie także solidaryzm - w skali makro jest nam potrzebna, bo człowiek w swym codziennym bytowaniu przekroczył najpierw granice własnej rodziny, a niedawno także granice własnego kraju. Nakazem czasu jest refleksja nad solidarnością rozumianą nie tyle jako indywidualna cecha człowieka czy małych grup społecznych, ale jako wielki plan dotyczący kształtu ładu społecznego, głównie - choć nie wyłącznie - tego ponadnarodowego (Markowski 2015).

Daty powstania napisów: 1980 i 2012, francuski źródłosłów i niebezpośredni związek z rewolucją francuską, wreszcie solidarność jako polemika z realnym komunizmem (socjalizmem) mogą otwierać rozmaite konteksty, w które wejdziemy (lub nie) zainspirowani wpisami uczniów w ostatniej rubryce tabelki. O ile więc wcześniejsze polecenia warto wykonywać w grupie, teraz bardziej przydatne dla dalszego toku zajęć mogą okazać się indywidualne wypowiedzi uczniów, zwłaszcza w kontekście poniższego cytatu:

[S]olidaryca ${ }^{3}$, jeden z naszych typograficznych hitów eksportowych, nie została nigdy skodyfikowana jako zestaw konkretnych znaków. Dlatego wciąż funkcjonuje jako dzieło niedokończone, otwarte na kolejne odczytania i modyfikacje (Szydłowska, Misiak 2015).

Dla pamiętających uniesienia pierwszej „Solidarności” napis z 2012 r. gorzko komentuje „polskie piekło”, które rozpętało się ze szczególną mocą po kwietniu 2010 r. Ale młodzi ludzie mogą dostrzec w nim zapowiedź nieuchronności indywidualizmu graniczącego z samotnością, na którą skazany jest człowiek doby portali (o ironio) społecznościowych. Już wydana w 1986 r. Solidarność i samotność Adama Zagajewskiego wobec dylematu

3 Wśród licznych przykładów użycia solidarycy, które można obejrzeć na: https://www.google.pl/sear$c h ? q=$ solidaryc $a+o b r a z y \&$ client $=$ opera\&hs $=h z r \& t b m=i s c h \& t b o=u \&$ source $=$ univ\&s $a=X \& v e d=0 C C 0 O$ SARqFQoTCLSB-oC21sCCFSKecgodB4EDwQ\&biw=1230\&bih=817 (dostęp: 01.09.2015), znajdują się także reklamy. Bardziej zgodne z przesłaniem pierwszego napisu są jej zastosowania np. w tytule i na okładce książki: Dekada. Czas nadziei i oporu, Poznań 1980-1989, pomysł i redakcja K. Laskowicz, Poznań 2005. 
wpisanego w tytuł stawiała artystę. Dziś nieobcy bywa on zwykłym ludziom, nawet tak zadowolonym jak Skandynawowie, którym szczęście nie przeszkadza czuć się samotnymi (Orliński 2015; Alexander, Sandahl, 2015).

\section{Od solidarności do wspólnoty, czyli odkrycie zasady porównania}

Odkrycie i zgłębianie zasady porównania przy rozmaicie zmodyfikowanym logo „Solidarności” wiedzie w różnych kierunkach. Ten związany ze wspólnotowością versus indywidualnością może okazać się szczególnie ważny dla młodych ludzi. Zwłaszcza jeśli w skupieniu zechcą przeanalizować trudny fragment ze wstępu Tadeusza Sławka do antologii przekładów Dystans i zaangażowanie, z którego zacytuję znamienny przykład:

warunkiem mądrej wspólnoty jest mozolne doświadczanie, uczenie się samotności. Wspólnota będąca jedynie gromadzeniem się wokół łączącej ją ideologii czy opinii nie zapuszcza korzeni zbyt głęboko (Sławek 2008, 7-8).

Natomiast samoświadome i ciągłe doskonalenie się jest tu postrzegane jako wysiłek jednostki, który w ostatecznym rachunku służy za podwalinę współczesnych wspólnot

niezamykających się w ciasnym horyzoncie przekonań, wyznań, rasy, narodu. Tego rodzaju grupowanie się jest wynikiem radykalnej wielości dróg; krocząc tymi drogami, jednostka może konstruować swoje życie; gromadzenie się wokół opinii czy sprawy (choć konieczne i nieuchronne w życiu publicznym) w znacznym stopniu na pewien przynajmniej czas skazuje nas na marsz jedną tylko drogą (Sławek 2008, 10).

Jest to wizja wspólnoty inkluzyjnej. Ale w poszukiwaniu kontekstu uczniowie powinni zostać nakierowani i na zupełnie inne widzenie wspólnoty zaprezentowane np. w książce Ksenofobia i wspólnota (Musiał, Wolniewicz 2003, 29-45). Wszystkie omawiane przez autorów teorie wspólnoty ${ }^{4}$ łączy konieczne odniesienie do tła, z którego - jak piszą - wspólnota musi się wyodrębnić, aby zyskać świadomość własnej swoistości i spójności. Według dynamicznej teorii wspólnoty z tła wydobywa ją określony układ sił wewnątrz- i zewnątrzwspólnotowych. Tak powstały związek ludzi cechuje: trwałość, duchowość (nie tylko interesowność), ekskluzywność (przynależność samoistna i dożywotnia skutkuje rozróżnieniem swoich i obcych), tradycja (jako spoiwo istotne także przy wychowaniu). Trwałość w ujęciu tych autorów jest niezbywalnym warunkiem związku ze wspólnotą, a jej rudymentarną gwarancją są „więzy krwi”, stąd siła wspólnot rodzinnych (wcześniej plemiennych) i narodowych.

Jak widać, zastosowano tu zupełnie inną perspektywę w widzeniu problemu niż we wcześniej wspomnianej antologii. Rozumienie wspólnoty przez Musiała i Wolniewicza jest osadzone w przeszłości (tak tworzyły się kiedyś wspólnoty). Ujęcie Sławka zaś rozważa wspólnoty nowej jakości

4 W tym podrozdziale autorzy omawiają jeszcze 1. delineacyjną teorię wspólnoty (najbardziej zbliżoną do tego, co tutaj proponuję uznać za zbiorowość); 2. deklaracyjną - członków wspólnoty łączy wówczas przede wszystkim przeświadczenie/deklaracja, że do tej wspólnoty należą (co zbliża ją do stowarzyszenia). 
(społeczeństwa obywatelskie), które mogą powstać dopiero na skutek rewizji tej przeszłości, gdy przynależność do wspólnoty tłumiła głosy jednostek.

Porównanie obu napisów może zatem prowadzić do rozróżnienia wspólnoty (napis 1) i zbiorowości (napis 2). Choć często wyrazy wspólnota oraz zbiorowość bywają stosowane zamiennie (jako synonimys) lub wspólnotę definiuje się jako typ zbiorowości, tutaj aż prosi się, aby pierwszy z omawianych napisów uznać za znak wspólnoty, a drugi - zbiorowości, odwołując się i do etymologii obu słów, i do ich upowszechnionego znaczenia. Zbiorowość to ogół ludzi wyodrębniony na podstawie jakiegoś kryterium, cechy, często pojedynczej, a nawet arbitralnie przyjętej - np. kryterium geograficzne, wiekowe, natomiast wspólnotę zazwyczaj łączy coś więcej. Co? Etos solidarności traktowanej już nie jako nazwa związku zawodowego, ale jako deklaracja wartości. Tak ujmował to ks. Józef Tischner:

Etos solidarności nie jest i nie był jednoznaczny. Wieloznaczność okazała się wartością. Słowo zawierało bowiem nie tyle opis jakiejś z góry żądanej rzeczywistości, ile otwarcie horyzontów dla rzeczywistości, która powinna zaistnieć. (...) Podsuwało myśl o kategorycznej potrzebie zmiany nie tylko systemu społecznego, lecz również całego sposobu bycia człowieka, w którym system się zakorzeniał. Słowo budziło odległe wspomnienia, podsuwało myśl o godności człowieka i o wartości heroizmu. (...) Bo etos solidarności, oprócz wszystkiego, był ekspresją najgłębszej ludzkiej i zarazem polskiej nadziei (Tischner 2005, 263).

Dlatego też jednoznaczność graficznego przesłania łatwo zakwestionować. Może napis z roku 2012 nie świadczy o rozpadzie wartości, które legły u podstaw ruchu z 1980 r., ale jedynie o mniej wyrazistym, mniej jednogłośnym ich wyrażaniu, które od jednostki nie wymaga takich wyrzeczeń, jak wspólnoty dawnego typu? A więc nie o katastrofie tu mowa, ale o korekcie „formy organizacyjnej” przyznawania się do dziedzictwa „Solidarności”?

W pierwszym napisie przekaz o niezbędności silnego zróżnicowania tła i wspólnoty, dobitnego „programu” (tj. kierunek nachylenia - opór rzeczywistości), który w znaczny sposób unifikuje cechy poszczególnych liter (choć nie zaciera całkowicie), wydaje się bardzo silny. Jeśli przyjąć jednak Tischnerowskie myślenie i założenie, że nadchodzi czas wspólnot inkluzyjnych, to trzeba będzie pomyśleć, co takiej wspólnocie nowego typu zapewnia trwałość i czy w ogóle istnieją jakieś niezbywalne, ahistoryczne wyznaczniki wspólnotowości. Czy rozmaite (a nie tylko tu zaprezentowane) modyfikacje logo „Solidarności” skłonią naszych uczniów do podjęcia tak fundamentalnej dyskusji?

Stanowić może ona dogodny punkt wyjścia do czytania Ody do młodości lub punkt dojścia, jeśli zechcemy Mickiewiczowską odę potraktować jako nieprostą przecież ilustrację tworzenia wspólnoty, dla tożsamości której niezbędne jest... wykluczenie.

5 Zob. http://synonim.net/synonim/zbiorowość (dostęp: 03.09.2015)

Polonistyka. Innowacje

Numer 2, 2015 


\section{Od napisów do Ody do młodości, czyli ku jakości opisu analitycznego}

Plastyczne kategorie: tła, kolorystyki, sugerowanego kierunku ruchu spróbujemy przyłożyć do Ody do młodości Adama Mickiewicza jako szczególnego manifestu rodzącej się wspólnoty.

Jacek Łukasiewicz (Łukasiewicz 2003, 24-37) przygląda się młodzieńczemu tekstowi Mickiewicza właśnie pod kątem budowania retorycznych ekwiwalentów tego, co dobre, choć w Odzie... dopiero projektowane, w relacji do tego, co złe, postrzegane w Mickiewiczowskim „tu i teraz”, ale przecież korzeniami tkwiące w krytykowanej przeszłości.

\begin{tabular}{|c|c|}
\hline $\begin{array}{l}\text { Ekwiwalenty tego, co DOBRE } \\
\text { (tak będzie) }\end{array}$ & $\begin{array}{l}\text { Ekwiwalenty tego, co } \mathbf{Z L E} \\
\text { (tak było i jeszcze jest) }\end{array}$ \\
\hline MŁODE ................. & STARE ...... \\
\hline NOWE .... Nowości potrzasa kwiatem ... & DAWNE ........ \\
\hline $\begin{array}{l}\text { WYSOKIE ........... dodaj mi skrzydła! } \\
\text { Niech }\end{array}$ & NISKIE ........... Patrz na dół ............... \\
\hline ZBIOROWE ....... ramię do ramienia .. & $\begin{array}{l}\text { INDYWIDUALNE .... Sam sobie sterem, } \\
\dot{z} \text { eglarzem, okrętem; ................... }\end{array}$ \\
\hline $\begin{array}{l}\text { SOLIDARNE ......... Jednościq silni, .......... } \\
\text { W szczęściu wszystkiego sq wszystkich } \\
\text { cele; }\end{array}$ & 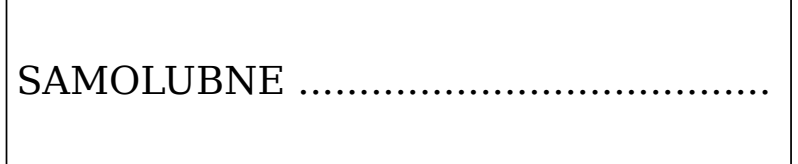 \\
\hline MŁODOŚĆ = PRZYSZŁOŚĆ & $\begin{array}{c}\text { PRZESZEOŚĆ = TERAŹNIEJSZOŚĆ } \\
=\text { STAROŚĆ = MARTWOTA }\end{array}$ \\
\hline
\end{tabular}

Tłem dla porywającego obrazu Młodości jako uosobionej, a nawet ubóstwionej idei (dlatego zapisałam wielką literą słowo młodość) jest obraz stagnacji, zamętu, nocy i starości. Retoryka inwokacji do Młodości nasuwa Łukasiewiczowi porównanie $\mathrm{z}$ uniesieniami obrzędów religijnych. Wyznawcy Młodości aspirują do bycia "my”- wspólnotą godną i gotową zmienić ten obmierzły świat, a właściwie zburzywszy stary, stworzyć nowy.

Siłą Ody do młodości jest ciągłe balansowanie między alegorią a konkretem, między obrazem a metaforą, między wąskim adresem - do grona przyjaciół a manifestem całego pokolenia, a nawet kolejnych pokoleń młodzieży. W tych ujęciach ciągle zderzane są aluzje i symbole współistniejące w kulturze, ale bez respektu dla ich różnego pochodzenia i znaczenia, np. 
Niechaj, kogo wiek zamroczy,

Chyląc ku ziemi poradlone czoło,

Takie widzi świata koło,

Jakie tępymi zakreśla oczy.

To bardzo konkretny obraz starca o ograniczonym polu widzenia i równie ograniczonej sprawności intelektualnej, czyli dotkniętego ślepotą duchową. Góruje nad nim Młodość, której boski lot i wzrok zrównany ze słońcem gwarantuje „przeniknięcie ludzkości z końca do końca”, ale co to właściwie znaczy? „Przeniknij” - to intuicyjne wniknięcie w nędzę ludzkości (następna strofa opisuje obszar gnuśności), a dlaczego nie również w jej radości, skoro i one istnieją („nektar żywota/Natenczas słodki ..../Serca niebieskie poi wesele")? Skąd ta jednostronność? Na jakiej zasadzie starzy wyłączeni są z owej ludzkości zasiedlającej Ziemię, którą młodzi zamierzają swoim entuzjazmem wytrącić z ustalonego biegu („Nowymi cię pchniemy tory,/Aż opleśniałej zbywszy się kory...”)? Skąd pewność, że to potrafią, skoro przed nimi nikomu się nie udało? Co oprócz wieku i dobrych chęci mogą przeciwstawić światu? Dla zaznaczenia sprzeciwu wobec zła młodość egzekwuje swoje prawa i sięga po retoryczne atuty hiperbolizacji i operowania kontrastem. „Nigdy takiej obfitości/By rozum był przy młodości" - pisał Jan Kochanowski, a i Mickiewicz z upływem lat widział młodość jako „górną i durną". Tego sceptycyzmu pozbawieni są młodzi w Odzie..., więc anektują dla siebie stwórcze zdolności i prawa, nie bacząc, że w ikonografii chrześcijańskiej Bóg przedstawiany jest właśnie jako czcigodny sta-

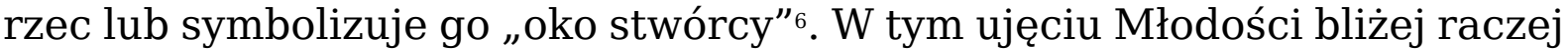
do herosów i bóstw mitologii grecko-rzymskiej („Dzieckiem w kolebce kto łeb urwał Hydrze"). Rówieśnikom Mickiewicza, absolwentom szkół klasycznych, biegłym w grece i łacinie, studentom profesora Gotfryda Ernesta Groddeka (zwanego Grodkiem), wystarczyły minimalne sygnały nawiązań do świata mitycznego i filozofii platońskiej, aby odtworzyć sobie ciągłość zamysłu przyjaciela-poety. Obecnie to zadanie dla literaturoznawców (Rudaś-Grodzka 2003), a nie naszych uczniów, ale dostrzeżone przez nich niespójności uświadamiają, że każda wspólnota ufundowana jest na jakiejś tradycji kulturowej. Jej nieznajomość także stanowi czynnik wykluczający (przynajmniej w jakimś stopniu), w tym przypadku wykluczający nawet ich, choć są przecież młodzi!!! W takim przypadku wiersz Mickiewicza traci na uniwersalności?

Zaskakuje także pojmowanie czasu w Odzie... W czasie teraźniejszym skażonym grzechami przeszłości nadzieje na świetlaną przyszłość dają jedynie więzy przyjaźni łączące młodych, skumulowana w nich energia, która

\footnotetext{
6 Zob. hasła Oko i Ślepota, w: Lurker 1989.
} 
zapowiada globalną rewolucję. Jednak dopiero po owocach rozpoznana zostanie przyszłość, ale wtedy młodzi będą już przynajmniej dojrzałymi, jeśli nie starymi ludźmi. W ogóle teraźniejszość i dojrzałość w tak ujmowanym porządku dziejów ludzkości i jednostki zdają się mało istotne, wręcz epizodyczne. Perswazyjne zacietrzewienie zakłóca bieg czasu: przeszłość stanowi opozycję do przyszłości, młodość do starości - milczeniem pokrywa się teraźniejszość, a jeszcze konsekwentniej dojrzałość. Dariusz Seweryn w wersyfikacyjnej i kompozycyjnej przewidywalności Ody...: następstwo strof inwokacyjnych wychwalających młodość i powiązane z nią wartości (przyjaźń, zapał, zdolność do poświęceń) oraz sugestywne opisy obmierzłego świata dostrzega drugie dno manifestu:

podczas gdy liryczny podmiot Ody zwiastuje jednorazowe moralne odrodzenie świata, jej poetycka struktura zdaje się wypowiadać myśl nieco inną, zabarwioną historycznym relatywizmem, głoszącym względność i przejściowość każdej dziejowej formacji (Seweryn 1997, 63),

a więc przekonanie o przemienności wspólnot pokoleniowych, które najpierw potrząsają „nowości kwiatem”, aby z czasem, z perspektywy następnego pokolenia zasłużyć również na zarzut bezwładu i marazmu. Z wyrozumiałością właściwą swemu wiekowi tę prawidłowość, nieoczywistą tylko dla młodych, komentuje Julia Hartwig:

Młodość jest dość dumna i pyszna, jej się zdaje, że jest jedyna taka. Ale potem człowiek się dowiaduje, że właściwie przynależy do tej samej rodziny co inni. Wiele tutaj nie można odmienić, tylko poczuć się solidarnie (Hartwig 2014).

Takich odkryć rodzi więcej czytanie tekstu zbrojone logiką. Warto do niej zachęcić młodych. Piorunujące wrażenie, jakie oda wywarła na przyjaciołach Mickiewicza, da się wyjaśnić śmiałym z perspektywy tradycji zastosowaniem przez poetę klasycznego gatunku. Jak dziś sprawdza się jego spatynowana innowacyjność?

Retoryczność gatunku ody kieruje ku pojęciowemu sposobowi lektury. Naoczność nie organizuje całości. Alegorycznej Młodości czy równie alegorycznego Zapału nie powinniśmy wizualizować. Pozostaje jednak wrażenie obrazowej konkretności poszczególnych elementów: szkieletu, potrząsania kwiatem, ale nie całości, w skład których wchodzą (Łukasiewicz 2003, 27).

Ale i dziś w Odzie... Mickiewicza oszałamia sugestywność obrazów i wręcz kalejdoskopowy rytm ich następstwa, śmiałość żonglowania symboliką kulturową, rozpiętość tonu. Zbyt tendencyjna wydaje się natomiast kolorystyka zestawien dwóch stron sporu o przyszłość ludzkości. Nie dość, że dla przedstawienia Młodości operuje się alegorią - wręcz ubóstwieniem pojęcia młodości, a po stronie martwej starości/przeszłości przywołuje się brutalne konkrety - obrazy zezwierzęcenia (płazy), to pociąga to za sobą równie jednoznaczny rozkład barw. Aureolę Młodości tworzy słońce, ogień, światło, a nade wszystko kolor złoty; minione - tonie w barwach szarości i nocy, których zamętu nawet mgła nie skryje. Napięcie manifestu, jego 
rozmach mogą budzić nie tylko zachwyt, ale i niepokój. Wizja wspólnoty „rozumnej szałem”, nawołującej, by gwałt odciskał się gwałtem, może skłaniać do zachowania ostrożnego dystansu niezależnie od tego, jakie młodzi stawiają sobie cele, a są one przecież bardzo ogólne. Może nawet ilustrują tylko przekonanie o omnipotencji?

Przeciwnym biegunem podziału bezsilność-kontrola jest omnipotencja. Jak wszystkie patologie osobowości jest to stan fantazji. Jednostka osiąga poczucie bezpieczeństwa ontologicznego dzięki fantazji dominacji (...). Jako mechanizm obronny, omnipotencja jest krucha i często psychicznie wiąże się z przeciwnym biegunem układu bezsilność-kontrola. Innymi słowy w sytuacjach krytycznych może przejść w swoje przeciwieństwo - pochłonięcie (Giddens 2001, 265).

Gdy zapytamy konkretnie, jak młodzi zamierzają ulepszać świat, okazuje się, że retoryka gatunku może stanowić „zasłonę dymną” tak scharakteryzowanego stanu uniesienia. Oda... współtworzy potęgę fikcji, w której - jak przypominał Kazimierz Wyka - „kategoria młodości stała się kategorią słuszności ideowej i artystycznej po raz pierwszy w takim rozmiarze" (Wyka 1974, 364). Kategoryczność tej zmiany ujawniła się w pełni dopiero w XIX wieku! Myli się jednak Wyka, pisząc dalej: dlatego zaś, „że po raz pierwszy, nigdy więcej nie powtórzy się w podobnej sile" (Wyka 1974, 364). Dziś przecież młodość jest nie tylko kategorią życia literackiego (to Wyka przewidział), ale i mentalno-społeczną. Nie wypada nie być młodym! Starość (a nawet dojrzałość) ma jakby mniejszą społeczną wartość niż młodość, więc współczesna nam cywilizacja europejsko-amerykańska nie poważa późniejszych faz życia w takim stopniu jak niegdyś. Warto korzeni takiej kulturowej postawy poszukać właśnie w romantyzmie, a Odę do młodości potraktować jako jeden z pierwszych przejawów ageizmu wym. ejdżyzmu, czyli dyskryminacji ze względu na wiek, tu: podeszły.

Od romantyzmu młodość bowiem przepoczwarzyła się w Młodość - wartość samą w sobie, rzeczywistość opartą na nierzeczywistych podstawach - wyobrażeniach, stała się „taką wizją jak każda inna, która żyje nadzieją na realizację, a kiedy do realizacji już dojdzie, dalej żyje nadzieją, tylko nie wiadomo na co" (Król 2004, 48). Choć Marcin Król zastosował to zdanie do charakterystyki innego fantazmatu ${ }^{7}$, doskonale ujmuje ono to, czym współcześnie stała się młodość, powiązana w Odzie... z przyjaźnią, miłością i pragnieniem wolności, jakby dojrzałość wszystko to wykluczała. Co się zatem stało, że zbiorowości, której podstawowym wyróżnikiem jest wiek biologiczny, przyznano statut ideowej wspólnoty? A jeśli dziś przewagi Młodości biorą się z tego, że tworzą ją młodzi i sprawniejsi... w korzystaniu z komunikacji internetowej?

7 Tymi słowami Marcin Król pisze o fantazmacie państwa narodowego. 


\section{Aktualizacja tendencyjnym doborem kontekstów(?), czyli odczyty- wanie sensów porównywanych tekstów}

Jeśli tak spojrzymy na wspólnoty dzisiejszych młodych, na to, jak sprawnie potrafią zorganizować np. flash-moby, czy równie znaczące ruchy Oburzonych w różnych krajach, to kwestia wspólnotowości jawi się jako istotne ogniwo zmiany współczesnego świata. Prasa pisze o młodych jednocześnie jako o nadziei i zagrożeniu dla demokracji (w takim kształcie jak dzisiejsza, neoliberalna). Fenomen poszukiwania sensu przez młodych analizują socjologowie (Standing 2015, Marody 2015). Ich „bunty służą wyłącznie do wyartykułowania gniewu" (Marody 2015) - twierdzą. I nie wiadomo, czy zdolni będą zmienić postać świata, czy poprzestaną na dobitnej retoryce. Pragnienie poparcia swoich pragnień, często mglistych, bardziej podbudowanych emocjami niż intelektualnymi poszukiwaniami bywa bowiem siłą napędową działań dostosowawczych. Tych, którzy poszukują autorytetów zdolnych wskazać im drogi korzystania z czasami niewygodnej wolności, przechwytują osobowości przywódcze.

Jaki jest związek między żartami typu flash-moby a ruchami Oburzonych? Sprawność technologiczna i zadomowienie w sieci to podstawowe warunki ich zaistnienia. Ale też sieć narzuca nową jakość kontaktów: kompulsywną, zwykle powierzchowną, zadaniową i nietrwałą. Czy tak powołane wspólnoty mogą zdziałać coś więcej niż happening? Wspólnotowość zdaje się więc stopniowalna: wspólnota idei nie zawsze wymaga sztywnych ram organizacyjnych, a organizacja nie musi wcale skutkować faktycznym poczuciem wspólnoty swoich członków, poza wspólnotą interesu. Solidarność wyrażona różnymi formami wsparcia (również materialnego) bywa często równie pożądana jak współczucie. Granica między wspólnotą a zbiorowością jest coraz mniej uchwytna.

Przywołane teksty kultury oprócz walorów związanych z tematem wspólnotowości, który bardzo łatwo uczynić rozmową o wyborach etycznych, ale i spłycić doraźną aktualizacją, mają i pomniejsze walory dydaktyczne. Każą zwrócić uwagę na sztukę użytkową, która nas otacza, np. na krój czcionek zastosowanych w napisach, tytułach, hasłach reklamowych, w ogłoszeniach, w nekrologach. Skupiają one naszą uwagę najczęściej wtedy, gdy swą wymyślną formą szkodzą informacji, którą mają przenosić. Tymczasem „litery nie są niewinne” nawet wówczas, gdy pozostają w cieniu komunikatu, „są tak samo bogatym źródłem wiedzy o kulturze jak gastronomia” przekonują Agata Szydłowska i Marian Misiak (Szydłowska, Misiak 2015). Przywołany tu i ciągle przetwarzany napis wnosi ze sobą kontekst historyczny i polityczny - stanowi doń wyrazisty, choć jak to próbowałam dowieść, niejednoznaczny komentarz. Porównywany zaś z klasycznym wierszem uderza kondensacją przekazu, każe na oba teksty spojrzeć, jak na dwie ody do wspólnoty, zrealizowane w różnych tworzywach. Odbiorca „gwałcony 
przez oczy” i przez tradycję szkolnej interpretacji może dać wyraz swojej reakcji na te formy perswazji, wykonując jeszcze inne zadania.

Poniżej kilka propozycji do wykorzystania na lekcji albo do realizacji w domu, by refleksje nad istotą wspólnotowości wzbogacić o dodatkowe akcenty.

1. Jak w kontekście dwóch pierwszych napisów (z 1980 r. i 2012 r.) odczytujesz rozwiązania graficzne zastosowane w trzecim napisie Solidarność (zob. zał. 3) z okładki „Polityki” 23-29.09.2015?

2. Zaprojektuj napis wyrażający istotne dla Ciebie wartości, korzystając $\mathrm{z}$ fontów dowolnego edytora tekstu lub innego programu graficznego.

3. Wskaż tekst (fragment) wiersza lub piosenki, który - Twoim zdaniem - potwierdza lub przeczy tezie: „jesteśmy istotami zarówno społecznymi, jak i indywidualnymi. Wchodzimy w najróżniejsze związki z innymi, w ostatecznym rozrachunku jednak zawsze samotnie stawiamy światu czoła”. Jakie retoryczne chwyty zastosowano w wybranym przez Ciebie tekście, aby „działał” silniej niż myśl powyżej wyrażona prozą.

4. Jaki wpływ na Twój odbiór Ody do młodości Mickiewicza mogłaby mieć zmiana pisowni w tytule i tekście słowa młodość na Młodość?

5. Jakiego rodzaju wspólnoty potrzebujesz Ty? Czy klasa szkolna powinna być wspólnotą? Jakie warunki musiałaby wówczas spełniać?

\section{Bibliografia:}

Alexander Jessica i Iben Sandahl (w rozmowie z Kaniewską A.), 2015, Popełniaj błędy, płacz i ciesz się życiem. Szczęśliwy jak mały Duńczyk, „Gazeta Wyborcza” 08.08.

Chrząstowska Bożena, 2009, O interpretacjach porównawczych; O interpretacji porównawczej po latach, w: Kwiatkowska-Ratajczak M., Wantuch W. (red.), Chrząstowska B., Przedmiot, podmiot i proces. Szkice z metodyki kształcenia polonistycznego, Poznań, s. 89-121.

Giddens Anthony, 2001, Nowoczesność i tożsamość. "Ja” i społeczeństwo w epoce późnej nowoczesności, Szulżycka A. (przeł.), Warszawa.

Hartwig Julia (w rozmowie z Dąbrowską J.), 2014, Wynagrodzona przez życie, „Gazeta Wyborcza” 31.10-2.11.

Kopaliński Władysław, 1971, Słownik wyrazów obcych i zwrotów obcojęzycznych, Warszawa.

Król Marcin, 2004, Patriotyzm przyszłości, Warszawa.

Lurker Manfred, 1989, Słownik obrazów i symboli biblijnych, 1989, bp Romaniuk K. (przeł.), Poznań.

Łukasiewicz Jacek, 2003, Oda do młodości, w: tegoż, Wiersze Adama Mickiewicza, Wrocław. 
Marean W. Curtis, 2015, Najbardziej inwazyjny gatunek, „Świat Nauki”, nr 9. Markowski Radosław (w rozmowie z Wężyk K.), 2015, Solidarność ma się opłacać, „Gazeta Wyborcza” 12-13.09.

Marody Mirosława (w rozmowie z Wężyk K.), 2015, Lud tego nie kupuje, lud się wkurza, „Gazeta Wyborcza”19-20.09.

Musiał Zbigniew, Wolniewicz Bogusław, 2003, Ksenofobia i wspólnota, Kraków.

Orliński Wojciech, 2015, Szczęśliwy jak wiking. Wolny rynek nie musi oznaczać nierówności, „Gazeta Wyborcza” 14.07.

Seweryn Dariusz, 1997, „... jak tam zaszedłeś”. Mickiewicz w szkole klasycznej, Lublin.

Sławek Tadeusz, 2008, Słowo wstępne, w: Dystans i zaangażowanie. Wspólnota literatura - doświadczenie. Antologia przekładów, Kadłubek Z., Sławek T. (red.), Katowice 2008.

Standing Guy (w rozmowie z Żakowskim J.), 2015, Przegrani, obcy sfrustrowani, „Polityka” 17-23. 06.

Szydłowska Agata i Misiak Marian (w rozmowie z Kierzynek A.), 2015, Litery nie sq niewinne „Gazeta Wyborcza” 22-23. 08.

Rudaś-Grodzka Monika, 2003 „Sprawić, aby idee śpiewały”. Motywy platońskie w życiu i twórczości Adama Mickiewicza w okresie wileńsko-kowieńskim, Warszawa.

Wyka Kazimierz, 1974, Pogranicze powieści, Warszawa.

Zbierski Paweł, 2012, Nowe logo na https://www.tygodnikpowszechny.pl/nowelogo-17050 (dostęp: 01.09.2015) lub w: Solidarność dzisiaj, dodatek specjalny do „Tygodnik Powszechny” 09.09.

\section{O Autorce:}

Wiesława Wantuch - doktor nauk humanistycznych, nauczycielka akademicka, wcześniej praktykująca w szkole podstawowej, obecnie członkini Pracowni Innowacji Dydaktycznych Uniwersytetu im. Adama Mickiewicza w Poznaniu. Autorka Aspektów integracji w nauczaniu języka polskiego (2005), Gier słów i rzeczy (2006) i licznych artykułów w „Polonistyce”. 
